\title{
AN OVERVIEW OF AQUACULTURE DEVELOPMENT IN VIET NAM
}

\author{
Tri NN*, Tu NPC, Nhan DT and Tu NV \\ Faculty of Fisheries, Nong Lam University, Vietnam
}

\begin{abstract}
Aquaculture has been successfully practiced in Viet Nam for centuries, but the sector still faces sustainable development challenges. This paper aims to briefly review the aquaculture development in Viet Nam, including history, the status of farming systems and key challenges to sustainable development. The sector was diversified in cultured species and environment, farming systems, intensified levels and consumed markets. Aquaculture has contributed significantly to the development of the country economy in terms of food security, income generation, restructure strategy in agriculture, international trade as well as the implementation of hunger alleviation and poverty reduction program. In 2019, aquaculture accounted for $54.31 \%$ of the total fisheries outputs (8.27 million MT); in which cultured fish accounted for $69.86 \%$ and cultured shrimp for $20.04 \%$ of aquaculture production (4.49 million MT). Among geo-ecological zones of aquaculture, the Mekong River delta has the highest potential for development due to its favorable conditions. In 2019 , the region accounted for around $72 \%$ of the total national aquaculture area and $70 \%$ of the total production; in which $71 \%$ and $84 \%$ of fish and shrimp production, respectively. The sector has contributed about $65-70 \%$ of seafood export values yearly. In 2020, the seafood export value of Viet Nam reached 8.5 billion USD. The country aquaculture was highly developed during the last three decades, particularly of striped catfish and marine shrimp farming, and driven by many factors such as state development policies, international collaboration, technological adaptation, etc. However, the sector is still facing challenges of sustainable development on disease control, environmental pollution, certification, small-scale household exclusion, etc.
\end{abstract}

Keywords: aquaculture, driving forces, history, sustainable development, Viet Nam

\section{Introduction}

Aquaculture has been practiced in Viet Nam for long time. There have been three main stages of the development of the aquaculture sector: an initial period from early 1960s until the reunification of the country in 1975, a second from 1975 to the application of renovation policy in 1986 and a third from 1986 until the present day. In the initial period, the aquaculture was mainly fish culture in ponds in freshwater areas. During the Viet Nam war (1963-1975), the aquaculture sector was practiced by cooperatives and state-run enterprises in Northern part and by small-scale farmers in Southern part to provide food fish for people. After 1975, the aquaculture sector was promoted in the whole country because of its importance in providing food and generating income for people. Several aquaculture farming systems such as fish culture in earthen pond in VAC (garden-fish pond-livestock pen) systems, rice-cum-fish, fish culture in lakes and reservoirs, fish culture in cage in rivers and extensive shrimp culture in mangrove forests. During the third stage of the sector history, aquaculture was oriented to export and encouraged to develop in the whole country from small-scale households to private and state-run enterprises in freshwater, brackish water and marine environments (Ministry of 
Fisheries (MoF) \& The World Bank (WB), 2005; Phuong \& Minh, 2005). Since 1990s, shrimp farming for export has been an important breakthrough. Since 2000s, striped catfish (Pangasianodon hypophthalmus) has become an important species in freshwater farming systems and stands the second in term of export value behind shrimps. The objectives of this paper are to review the history of aquaculture development, describe the status of farming systems and analyze the roles of driving forces of the development and challenges of the sustainability. Future directions and needs are also proposed for improving the sustainable development of the Viet Nam aquaculture.

\section{Materials and Methods}

This paper has been prepared using secondary data from General Statistics Office (GSO) and Ministry of Agriculture and Rural Development (MARD) of Viet Nam, Vietnam Association of Seafood Exporters and Producers (VASEP) and Food and Agriculture Organization of the United Nations (FAO). During preparing this paper different journals, books, thesis were reviewed, etc. All data were analyzed, and graphs are generated using Microsoft Excel.

\section{Results and Discussion}

\section{Current state of aquaculture production}

The area under aquaculture was increased at a high growth rate, particularly of brackish water aquaculture. Addition to increased culture area, the aquaculture sector was also diversified in cultured species and systems, and intensified in stocking density and inputs (Tuan, 2003; Phuong \& Minh, 2005; Vinh, 2006). These resulted in an increase of farming yields and outputs. Aquaculture production has been continuously increased at an average growth rate of $12.77 \%$ annually. Since 2007, aquaculture production has exceeded over that of capture fisheries. In 2019, aquaculture accounted for $54.31 \%$ (4.49 million MT) of the total fisheries outputs (8.27 million MT); in which cultured fish accounted for $69.86 \%$ (3.14 million MT) and cultured shrimp for $20.04 \%$ (899.84 thousand MT) of aquaculture production (Figure 1) (GSO, 2021).

In general, aquaculture has gradually changed from a self-sufficient sector into one of the key commodity productions of the country. It has obtained an important position in national economy. Aquaculture has been playing a very important role in the economic restructure strategy in agriculture as well as the implementation of hunger alleviation and poverty reduction program in different regions of the country (JICA, 2013; N. T. K. Anh et al., 2016). In 2019, the sector contributed to $24.4 \%$ of the GDP of agro-forestry-fishery production and 3.4\% of national economy (GSO, 2019). In 2021, the central government approved the strategy of Viet Nam fisheries development until 2030, and vision until 2045; in which targets are set for the national fisheries by the year of 2030 as follows: a yearly growth rate of 3-4\%, a total production of 9.8 million MT (of which, 7 million MT from aquaculture), a seafood export value of 14-16 billion USD and a job provision of more than 3.5 million labor work (The Prime Minister of Viet Nam, 2021). 


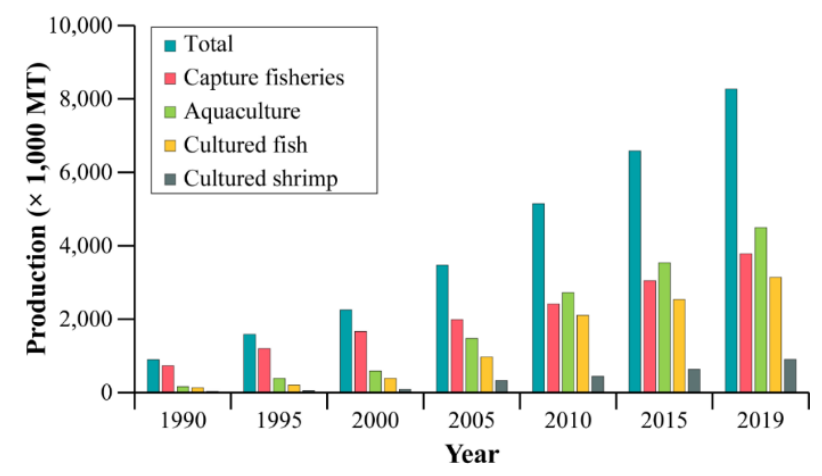

Figure 1: Development of Viet Nam capture fisheries and aquaculture production (Source: GSO, 2021)

Since 2005, Viet Nam has become the fourth among major aquaculture producers of Asian region as well as the world after China, India and Indonesia. The contribution of the country to total world aquaculture production has increased from $3.24 \%$ in 2005 to $5.04 \%$ in 2018. In 2018, Viet Nam was one of the four countries who produced aquaculture production exceed the 50 percent of total fish production included China (76.5\%), India (57.0\%), Viet Nam (55.3\%) and Bangladesh (56.2\%). Aquaculture of Viet Nam has been developed in both inland, and marine and coastal areas. The country occupied the fourth and eighth positions among major producers of inland, and marine and coastal aquaculture, respectively. Striped catfish farming was dominated in inland aquaculture and marine shrimp farming was dominated in marine and coastal aquaculture. Viet Nam was the third biggest producer of shrimps of the world. Since 2014, Viet Nam has become the third major seafood exporter after China and Norway (FAO, 2020).

\section{Aquaculture distribution by agro-ecological zones}

Viet Nam has a coastline of $3,260 \mathrm{~km}$, with a maritime territory of $226,000 \mathrm{~km}^{2}$ and an Economic Exclusion Zone of 1 million $\mathrm{km}^{2}$, as well as with many estuaries, bays, more than 400,000 ha of mangrove, rivers, rice-irrigation canals and hydro-electric dams. These resources create a great potential for Viet Nam to develop seafood industry, including both aquaculture and fishing sectors. The potential area for aquaculture development of Viet Nam is about 1,700,000 ha of the land mass. In the country, aquaculture systems are diversified according to agro-ecological zones with different geographical and climatic conditions (Phuong \& Minh, 2005; Vinh, 2006; Viet, 2013) (Figure 2), as follow:

- North mountain and midland, included northeast and northwest, is dominated by freshwater fish farming in ponds, bamboo cage and rice fields.

- Red river delta (RRD) is dominated by farming freshwater fish in ponds, marine shrimp in ponds, bivalves in tidal beds and marine fish in cages.

- Central coast, included north and south, concentrates on farming marine shrimp in ponds, lobster and marine fish such as cobia, Asian seabass and grouper in cages.

- Central highland is dominated by farming of freshwater fish in ponds and cages.

- Southeast is dominated by farming freshwater fish in ponds and cages, marine shrimp and fish in ponds. 
- Mekong river delta (MRD) has the most diversified farming activities that include striped catfish culture in ponds and cages as well as tilapia and several indigenous species culture such as snakehead fish, climbing perch, etc. in ponds and giant river prawn in rice fields, various intensification levels of marine shrimp in ponds, rotated in rice fields and integrated in mangroves.

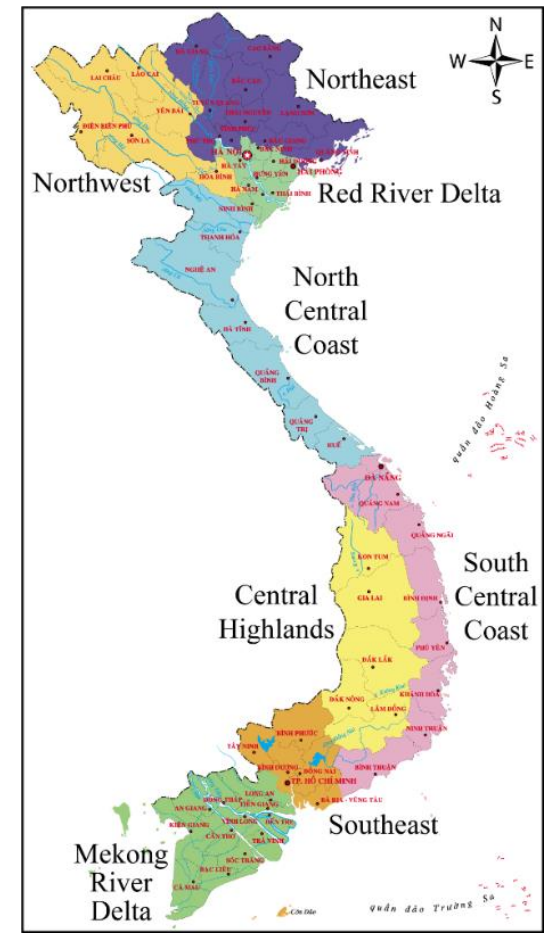

Figure 2: Aquaculture zones based on geo-ecological conditions of Viet Nam

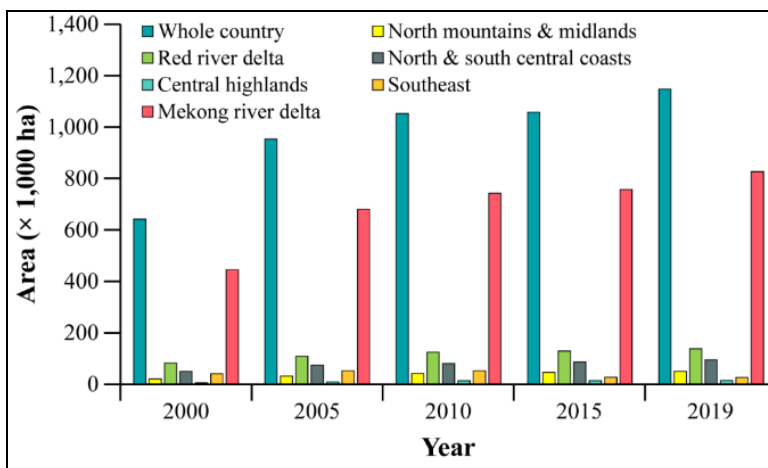

Figure 3: Area of Viet Nam aquaculture and its agroecological zones (Source: GSO, 2021)

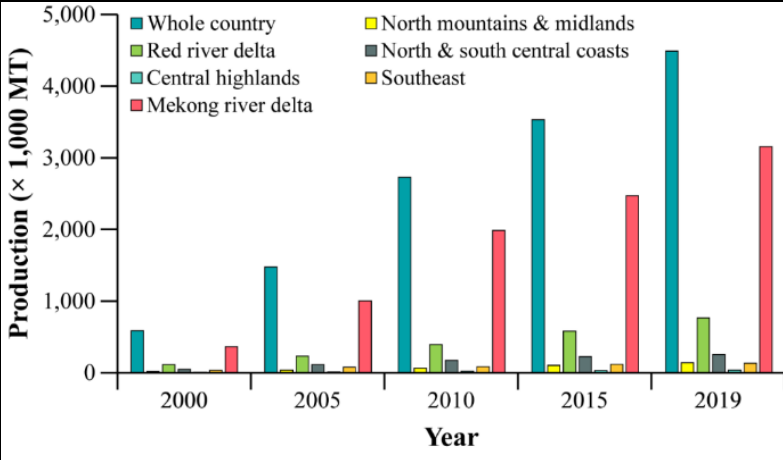

Figure 4: Production of Viet Nam aquaculture and its agro-ecological zones (Source: GSO, 2021)

Aquaculture is concentrated in the MRD provinces due to its favorableness of geographical and climatic conditions. In 2019, the region was accounting for around $72 \%$ of the total national aquaculture area and $70 \%$ of the total production; in which $71 \%$ and $84 \%$ of fish and shrimp production, respectively (Figures $3 \& 4$ ).

\section{Aquaculture distribution by environment}

Viet Nam aquaculture systems are also diversified according to environment (Figure 5). 


\section{Freshwater aquaculture}

Polyculture system in earthen ponds has been traditionally practiced in Viet Nam for long time. It is applied at small-scale and semi-intensive level. Cultured species are different according to geographical regions. In Northern and Central highland of Viet Nam, common carp, Chinese carps (silver carp, bighead carp and grass carp) and Indian major carps (rohu, catla and mrigal) are main species cultured in the system. In Southern Viet Nam, tilapia is the main species combined with common carp, Indian major carps and indigenous species. In Northern and Central highland regions, organic manure is commonly applied to develop natural feed (phytoplankton plus zooplankton) for cultured fish. In general, the fish is fed with agricultural by-products and home-made feed and irregularly with industrial feed. With a density of 3-5 fish $\mathrm{m}^{-2}$, the yield of the system can be 3-10 MT per hectare (ha). The harvested fish is supplied to local markets through middlemen or farmers themselves.

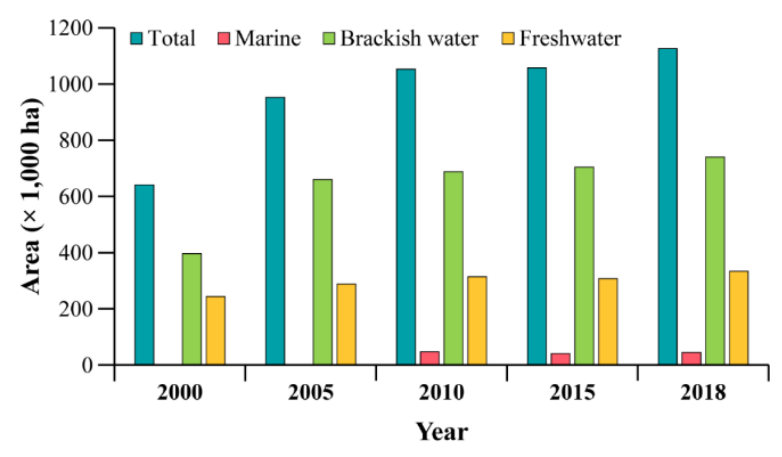

Figure 5: Aquaculture area of Viet Nam shared by different farming environments

Monoculture system in ponds and cages has been recently developed in Viet Nam, particularly in the RRD and MRD. Main cultured species in the RRD is tilapia. The cultured species in the MRD is more diversified with striped catfish, tilapia, hybrid walking catfish, climbing perch, snakehead fish and freshwater giant prawn. The system is intensified in terms of stocking density, feeding and management. The cultured fish is supplied with home-made feed or commonly with industrial feed (Edwards et al., 2004). The yield of the system is high, particularly for snakehead fish and striped catfish. The harvested product is supplied as food fish to domestic markets and as raw materials for processing and export through wholesalers and middlemen.

The culture of Pangasiids started around 1950s in the MRD, of which striped catfish (Pangasianodon hypophthalmus) was raised in 'over-hung latrine pond' while basa catfish (Pangasius bocourti) in floating wooden cage in rivers (De Silva \& Phuong, 2011; N. L. Anh, 2014). The development of striped catfish farming industry is considered a success story of aquaculture in Viet Nam (De Silva \& Phuong, 2011). The development of striped catfish farming systems based on research findings and innovations can be summarized in Figure 6 .

In the beginning, it was a small-scale aquaculture, providing food for household demands only. The stocked seed of both species was wildly caught from the Mekong River. Due to the shortage of wild fingerlings, early trials of artificial propagation of striped catfish were carried out by Vietnamese researchers in early 1980s. For almost two decades of efforts, results of the artificial propagation of striped catfish were limited with bottle-necks of low ratios of breeder spawning, egg fertilization and larval survival. With the cooperation of French researchers, a breakthrough of artificial propagation of 
striped and basa catfish occurred in 1997 (Cacot, 1998) and the bottle-necks were gradually overcome. Thereafter, seed production techniques of striped catfish were developed and quickly disseminated to fish seed hatcheries in the MRD (Tam et al., 2010).

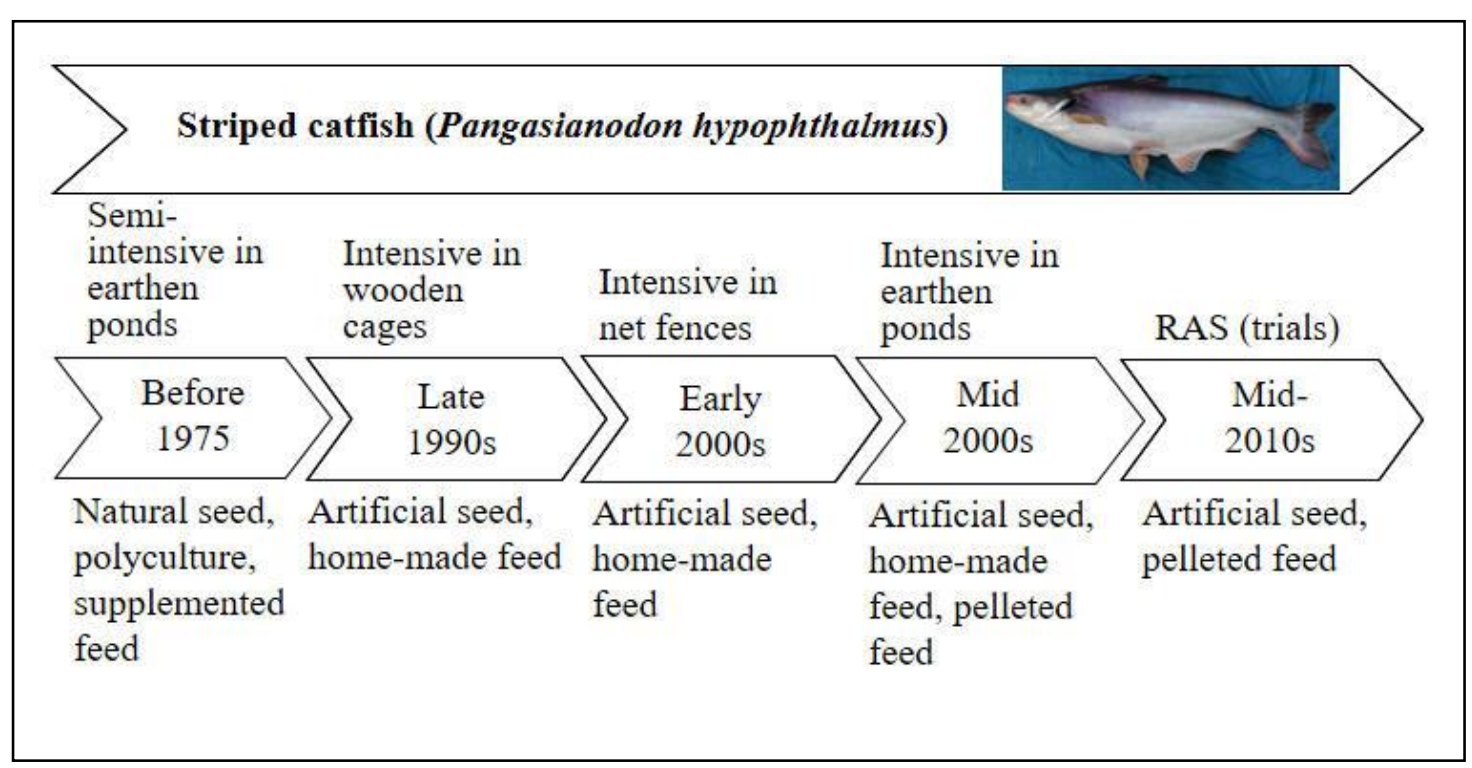

Figure 6: Time frame of the development of striped catfish farming systems in Viet Nam

The success of first exportation of basa and then striped catfish fillets to US market in mid-1990s and the availability of artificial seed supply made striped catfish farming progressively developed to meet the demand of raw material for processing and export. Due to the lack of understanding laws of the import country, striped catfish fillets were faced the US Anti-Dumping (AD) Duty Investigation proceeding, which commenced in 2001 and imposed AD duties in 2003 (Petteway, 2004). The US was the only market of striped catfish until the $\mathrm{AD}$ case. Luckily, the case was an unexpected advertisement to publicize striped catfish products to other international markets (van Duijn et al., 2012).

During the last two decades there has been a marked transformation of striped catfish farming systems in the MRD. Before 2001, three farming systems namely cage, pond and pen (fence) culture contributed almost equally to the total production of striped catfish. However, since 2003 pond culture has gradually been developed, and this system currently dominates the striped catfish farming industry in the MRD (Lam et al., 2009). Pond farming has become the dominant production system because of relatively faster growth rate of cultured fish, lower production cost, and better flesh quality and appearance meeting criteria of the international markets. Concerning environmental problems from pond culture of striped fish, recirculation technology RAS has been successfully tried (Nhut, 2016). The production of striped catfish was 1.5 million MT in 2020 (GSO, 2021). 


\section{Brackish water aquaculture}

Brackish water aquaculture is generally referred to the culture of crustaceans such as shrimp, mud crab and Asian seabass in coastal earthen ponds. The development of shrimp farming systems based on research findings and innovations can be summarized in Figure 7.

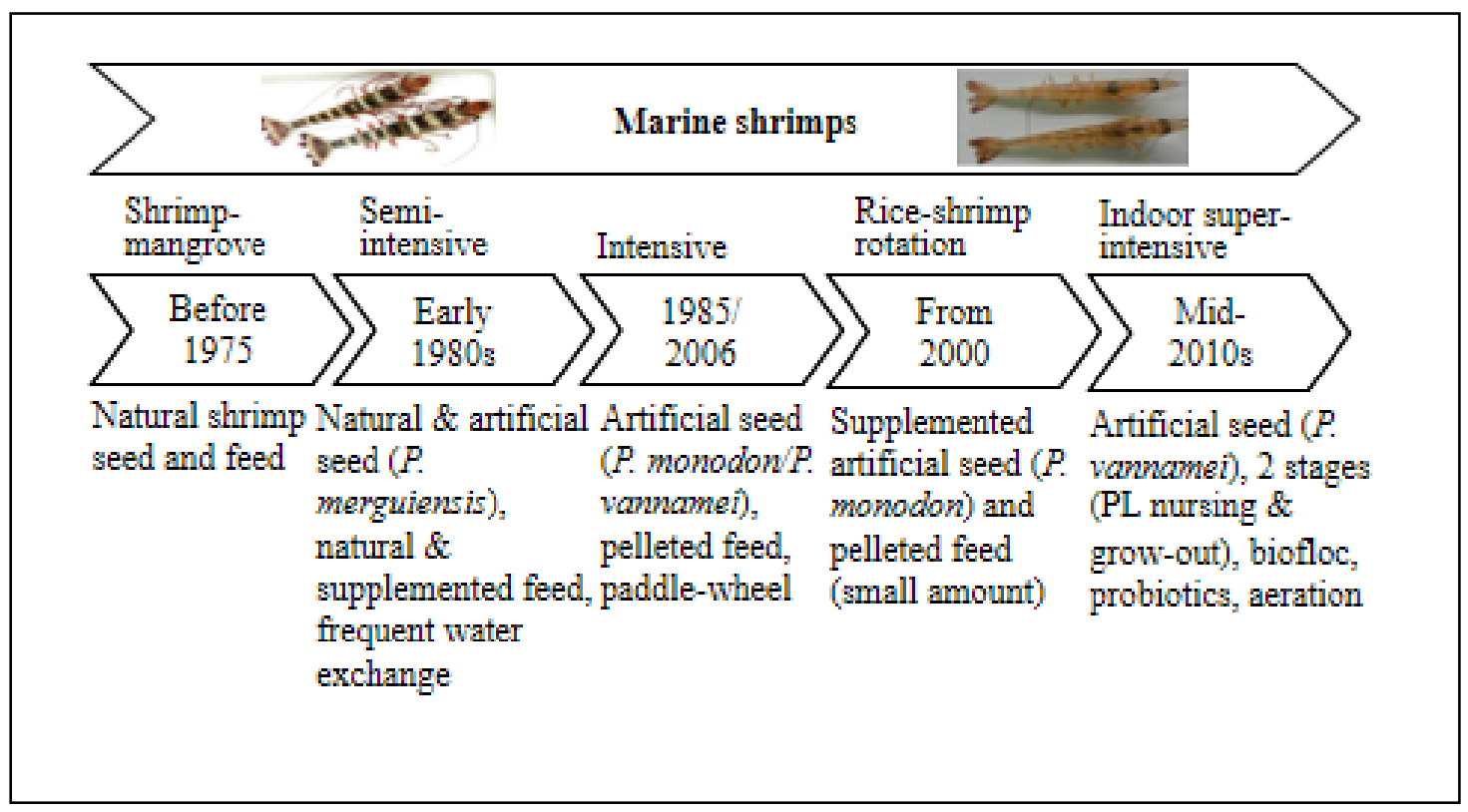

Figure 7: Time frame of the development of shrimp farming systems in Viet Nam

Integrated mangrove-shrimp system is a traditional form of raising shrimp that is markedly different from other production forms mainly in the coastal areas of the MRD. In this system, mangrove trees are remained about $40-70 \%$ of pond area. This extensive polyculture is characterized by no feed input, no fertilization, passive water exchange and low production. To improve production, hatchery-reared black tiger shrimp (BTS) (Penaeus monodon) postlarvae (PL) are frequently stocked at low density. The total production is $492 \mathrm{~kg} \mathrm{ha}^{-1}$ year-1 in average, of which $193 \mathrm{~kg}$ of cultured shrimp $153 \mathrm{~kg}$ of wild shrimp such as banana shrimp ( $P$. merguiensis), Indian shrimp ( $P$. indicus), sand shrimp (Metapenaeus ensis), etc. (Hai et al., 2015).

With simple techniques, low capital investment, environmental friendliness, regular harvests, little disease and few economic risks, this system is close to organic production criteria. By the year of 2010, around 1,000 integrated mangrove-shrimp farms with a total area of 6,000 ha had been certified organic production by the German organic certification scheme Naturland and audited by other international certification organizations in the following years (Jonell \& Henriksson, 2015).

The improved extensive shrimp farming system occupies about 330,000 hectares in the MRD. Different from the earlier system, there are no mangrove trees in ponds. In this system, wild shrimp, fish and crabs flow into ponds through tidal water exchange during the full moon and new moon. To improve harvest, hatchery-reared BTS PL are stocked several times during cultured period at low density. Mud crabs, blood cockles (Anadara granosa) and some brackish water fish are also stocked at low density to make use of natural food and for diversification of products and income. No or low supplemental feed is used. The total productivity is $432 \mathrm{~kg} \mathrm{ha}^{-1}$ year $^{-1}$ in average, of which $213 \mathrm{~kg}$ of cultured shrimp $95 \mathrm{~kg}$ of wild shrimp (Hai et al., 2015). 
The rotated rice-shrimp farming system was developed in 2001 in the MRD when the government allowed to shift inefficient planned rice field areas to aquaculture. This system currently occupies for more than 160,000 ha, where BTS is cultured in the dry season with brackish water and rice is cultivated in rainy season with freshwater. The pond/field is surrounded with deep ditch along the dyke and a flat area in the center. Casual feeding and simple management are practiced with low stocking density, and well feeding and water management with high stocking density. After a shrimp crop of 3-4 months, the yields of 200-300 kg ha-1 $\mathrm{crop}^{-1}$ can be obtained for low stocking systems and $800-1,500 \mathrm{~kg} \mathrm{ha}^{-1} \mathrm{crop}^{-1}$ for high stocking ones (Hai et al., 2015).

Semi-intensive and intensive farming systems with BTS were developed in the middle of 1990s in southern central coastline provinces. However, the MRD has become biggest shrimp production area due to its favor conditions for shrimp farming. Since 2008 majority of intensive shrimp farms have shifted from BTS to whiteleg shrimp (WLS) (Litopenaeus vannamei) due to its advantages of short culture duration, high production, low risks of diseases and loss. Generally, earthen or HDPE-lining intensive shrimp ponds are rather small in area (0.2-0.5 ha). Stocking densities are higher for WLS (70-150 PL m${ }^{-2}$ ) compared to BTS (20-35 PL m²). Shrimp seed is normally checked for pathogens of common diseases such as white spot syndrome disease (WSSV) and acute hepatopancreatic necrosis disease (AHPND) before stocking. The cultured shrimp is fed with industrial feeds. Water exchange is limited so the intensification of management such as aeration, daily environment checking, probiotics use, etc. is also applied. After 90-100 days of culture for WLS and 100-150 days for BTS, shrimps are harvested with yields of 10-15 tons ha ${ }^{-1}$ crop $^{-1}$ and 3-7 tons ha ${ }^{-1}$ crop $^{-1}$ for WLS and BTS, respectively (Hai et al., 2015).

Although the management of intensive shrimp systems has been improved, the problem of diseases has still been big issues of the industry. To mitigate the problem, some modifications have been applied recently. In single phase farming, the shrimp seed is stocked in the same pond until harvested after 3-4 months of culture. In double phase farming, shrimp PLs are first stocked in nursing ponds at a density of 500-1,000 $\mathrm{PL} \mathrm{m}^{-2}$ for 20-30 days. The shrimp at a size of 2-3 $\mathrm{g}$ is then moved to grow out ponds at a lower density of 100-150 inds $\mathrm{m}^{-2}$. The shrimp is harvested after 2-3 months of farming at a size of 30-35 g. Triple phase farming practice may be applied by moving the shrimp twice after nursing phase to extend the culture duration for bigger size at harvesting.

Biofloc provides two important roles in organic waste management and supply good nutrition feed for cultured animals. Biofloc technology is applied by adjusting C:N ratio of and supplying probiotics to highly aerated pond environment to convert organic waste into protein source for cultured shrimp. WLS culture with biofloc technology has higher stocking density, needs higher investment, and is applied mainly in the central coastline provinces.

Indoor shrimp culture technology is widely used in advanced countries. In Viet Nam, this method has been first applied in Bac Lieu province in the MRD. Culture pond is made of HDPE sheet covered set inside a metal frame. The system is well equipped with functioning facilities for water quality management. Water can be treated and reused is the advantage but very high initial investment is the main constraint of this system. Shrimp is stocked at very high density of 200-300 inds $\mathrm{m}^{-2}$. After 100105 days of farming, the shrimp is harvested at a size of 30 inds $\mathrm{kg}^{-1}$ and the yield reaches about 80 tons $\mathrm{ha}^{-1}$. The production of marine shrimps was 0.95 million MT in 2020 (GSO, 2021). 
Farming high value fish in brackish water has been developed recently due to the problem of shrimp diseases and economic losses, and high profit of fish culture. The main cultured species is Asian seabass (Lates calcarifer) with seed produced artificially. The fish is stocked in ponds previously used for shrimp farming and fed with industrial feed. The fish production management practice adapted from intensive shrimp farming systems.

\section{Marine aquaculture}

Marine aquaculture is mainly water-based systems with different farming species. The marine aquaculture has just been developed recently. Fish cultured species in marine environment of Viet Nam are diversified with groupers (Epinephelus bleekeri, E. akaara, E. sexfasciatus, E. malabaricus, E. coioides, E. merra and Cephalopholis miniata), cobia (Rachycentron canadum), Asian seabass ( $L$. calcarifer), red drum (Sciaenops ocellatus), Pompano (Trachinotus sp.), snapper (Lutjanus sp.), red sea bream (Pagrus major), rabbit fish (Siganus guttatus), yellow tail (Seriola dumerili), sand bass (Psammoperca waigiensis), etc., in which grouper, cobia and seabass are the most popular marine cultured fish species (Edwards et al., 2004). Marine fish farming is mainly performed in floating net cage systems (Tuan, 2003). In the period 2010-2015, the number of marine fish cages were continuously increased, from 30,031 units in 2010 to 172,119 units in 2015 (MARD, 2015). Seed of most marine cultured species has been artificially produced but some (grouper, snapper, red sea bream, rabbit fish, yellow tail, sand bass) still partly relied on wild fry. Both trash fish feed (FCR 4.510) and industrial feed (FCR 1.8-2.4) are used in marine fish farming systems (MARD, 2015).

Spiny lobster farming is flourishing in five south central coastline provinces. Fixed, floating and submerged cages are used for lobster culture. The number of lobster cages in 2010 was 51,797 units, increased up to 56,942 units in 2015 (MARD, 2015). Lobster production was also increased from 1,397 tons to 1,657 tons in respective years (MARD, 2015). The farming spiny lobster species are tropical rock lobster (Panulirus ornatus), green lobster (P. stimpsoni), red lobster (P. longipes) and bamboo lobster ( $P$. polyphagus), in which tropical rock lobster is the main species (74.2\%), followed by green lobster $(22.7 \%)$, bamboo lobster $(1.9 \%)$ and red lobster $(1.2 \%)$. Until now lobster farming has still relied on wild inputs of seed and feed (MARD, 2015).

Seaweed culture in Viet Nam is concentrated in the southern central coastline region with species of cottonii (Kappaphycus alvarezii) and sea grape (Caulerpa lentillifera). The area of seaweed cultivation tends to decrease year by year due to unstable market and unfavorable weather, especially in the fog season (MARD, 2015).

\section{Aquaculture-based seafood export}

Aquaculture products are supplied for both domestic and foreign markets. In the domestic markets, cultured aquatic animals are consumed mainly in fresh and live forms. A minor amount of aquaculture harvests is consumed in the form of processed products such as dried fish, dried shrimp, spicyfermented fish, frozen fish ball, etc.

The development of Viet Nam aquaculture is increasingly focused on export and the production of high-value species. Two major seafood export commodities of Viet Nam are marine shrimps and striped catfish (Figure 8) which raw materials for processing come from aquaculture (approximately 
$50 \%$ of total aquaculture volume in general and $100 \%$ of cultured striped catfish in particular). Frozen products such as fish fillet, whole fish and shrimp are main exported seafood of Viet Nam. The ratio of export turnover of value-added seafood products has been increased recently, accounted for 35\%. In 2019, Viet Nam was the third largest seafood exporter in the world by value and exported seafood products to 158 countries and territories (GSO, 2021).

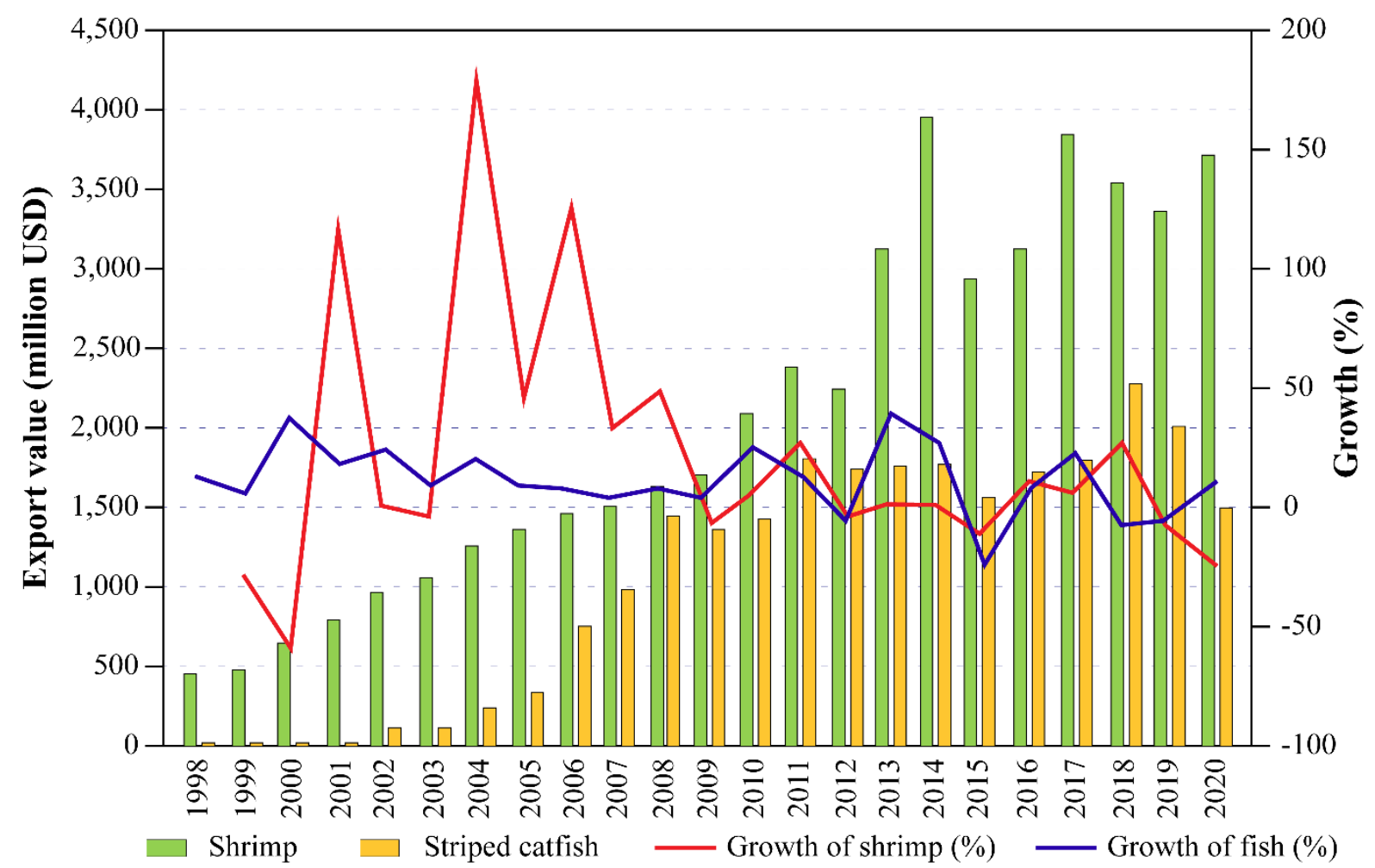

Figure 8: Export values of striped catfish and shrimp products by years (Source: VASEP, 2021)

\section{Driving Forces of Viet Nam Aquaculture Development}

The development of Viet Nam aquaculture has been driven by many factors included state investments in planning, research, education, training and technology transferring, international collaboration, quick adaptation of farming species and method, cooperation among stakeholders and support of non-government organizations (NGOs).

\section{State investments}

Regarding the management structure operating in the country, the central government is the highest executive organ. It is responsible for the issue of development strategies of the national fisheries. The MARD is responsible for implementing the country strategies and building long term and annual plans of development, proposing national standards and issuing national technical regulations of related fields namely agriculture, forestry and fisheries (AFF). People's committees are responsible for implementing annual plans of development of AFF at provincial levels (Tuan, 2003; Phuong \& Minh, 2005).

To achieve targets of the program of hunger alleviation and poverty reduction and the policy of restructuring agriculture, the central government and the MARD have paid much attention on 
fisheries. Capture fisheries in Viet Nam are being shrunk and do not employ as many people. Aquaculture is a tool for providing jobs in rural areas and raw materials for seafood processing and export (Hishamunda et al., 2009). These managerial bodies have issued many decisions to support the development strategies and plans of fisheries in general and aquaculture in particular.

The MARD controls all of its institutions in order to achieve targets of the issued development strategies, annual and long-term plans. The specialized institutions which support the MARD in terms of research and development are Research Institute for Marine Fisheries (RIMF), Institute for Fisheries Economic and Planning (IFEP), Research Institute for Aquaculture No. 1 (RIA1 - based in the North), Research Institute for Aquaculture No. 2 (RIA2 - based in the South), Research Institute for Aquaculture No. 3 (RIA3 - based in the Central). These institutions have carried out research to support national and provincial development plans with funding sources from the MARD and provinces (Table 1).

The development of the fisheries in general and aquaculture sector in particular has been greatly contributed by educational institutions in terms of human resource building and technology dissemination. There have been close interactions between the development of aquaculture production and education. During the development of the sector, the number of institutes offering training programs on aquaculture has been increased from three (two universities and one college) in 1975 to 19 (13 universities and 6 colleges) in 2018. Most of them are located in the MRD, the highest potential region of aquaculture development of the country. The training programs have also been more and more diversified in fields, forms and degrees of study to meet the demand of human resource for the development of the sector (Tu et al., 2019).

There are national and provincial agriculture extension centers with skilled staff to support the development of the fisheries sector by offering technical training to farmers (Phuong \& Minh, 2005). This is also contributed by unions and associations such as Viet Nam Fisheries Society (VINAFIS), Viet Nam Pangasius Association (VINAPA), VASEP, etc.

Table 1: Typical research carried out by institutions of the MARD during the last ten years

\begin{tabular}{lll}
\hline Research & Status & Note \\
\hline $\begin{array}{l}\text { Application of advanced technology to produce } \\
\text { specific pathogen free strain of BTS (Penaeus } \\
\text { monodon) }\end{array}$ & Finished in 2010 & \\
\hline $\begin{array}{l}\text { Application of advanced technology to produce } \\
\text { specific pathogen free strain of WLS (Litopenaeus } \\
\text { vannamei) }\end{array}$ & Finished in 2011 & \\
\hline $\begin{array}{l}\text { Application of biofloc technology (BFT) in } \\
\text { intensive farming of WLS }\end{array}$ & Finished in 2013 & \\
\hline $\begin{array}{l}\text { Seed selection of striped catfish (Pangasianodon } \\
\text { hypophthalmus) for high growth rate and fillet } \\
\text { ratio }\end{array}$ & From 2001 to 2016 & $\begin{array}{l}\text { Selected seed } \\
\text { disseminated }\end{array}$ \\
\hline $\begin{array}{l}\text { Seed selection of red tilapia for high growth rate } \\
\text { and acceptable color }\end{array}$ & From 2008 to 2016 & $\begin{array}{l}\text { Selected seed } \\
\text { disseminated }\end{array}$ \\
\hline $\begin{array}{l}\text { Seed selection of giant freshwater prawn } \\
\text { (Macrobrachium rosenbergii) for high growth and }\end{array}$ & From 2008 to 2014 & $\begin{array}{l}\text { Selected seed } \\
\text { disseminated }\end{array}$ \\
\hline $\begin{array}{l}\text { survival rates } \\
\end{array}$ & & \\
\hline
\end{tabular}




\begin{tabular}{lll}
\hline $\begin{array}{l}\text { Application of molecular and numerical genetics in } \\
\text { preliminary seed selection of Asian seabass (Lates } \\
\text { calcarifer) for high growth rate }\end{array}$ & Finished in 2017 & \\
\hline $\begin{array}{l}\text { Development and application molecular marker in } \\
\text { broodstock selection of WLS (Litopenaeus } \\
\text { vannamei) for high growth rate }\end{array}$ & Finished in 2018 & \\
\hline $\begin{array}{l}\text { Production of IgY to prevent and treat diseases } \\
\text { caused by Vibrio spp. on WLS (Litopenaeus }\end{array}$ & Finished in 2020 & \\
vannamei)3 & & Finished in 2020 \\
\hline $\begin{array}{l}\text { Building a model of effective prevention and } \\
\text { treatment for lobster culture in cages }\end{array}$ & $\begin{array}{l}\text { Advanced } \\
\text { technique } \\
\text { certified }\end{array}$ \\
\hline
\end{tabular}

Source: ${ }^{1}$ Research Institute for Aquaculture No. 1 (RIA1) (2021), ${ }^{2}$ Research Institute for Aquaculture No. 2 (RIA2) (2021), ${ }^{3}$ Research Institute for Aquaculture No. 3 (RIA3) (2021)

\section{International collaboration}

Provision of seed supply with high quality and enough amount is the first condition to develop farming a species. Technology and innovation have played an important role in aquaculture development of Viet Nam, particularly during the second phase of the sector. Due to difficulties of human and funding resources for research of the country, the transfer of technologies in seed production through international collaboration projects has been a driving force of the related species as well as the sector development. Some typical technologies transferred, and their impacts are listed in Table 2.

Table 2: Impacts of technology transfer through international collaboration to the development of Viet Nam aquaculture

\begin{tabular}{|c|c|c|c|c|}
\hline Technology & Collaborator & Donor & Year & Impact \\
\hline $\begin{array}{l}\text { Seed production of giant } \\
\text { freshwater prawn }(M . \\
\text { rosenbergii })^{1}\end{array}$ & $\begin{array}{l}\text { The Australian Centre for } \\
\text { International Agricultural } \\
\text { Research (ACIAR) }\end{array}$ & $\begin{array}{l}\text { Australian } \\
\text { government }\end{array}$ & 1985 & \multirow{2}{*}{$\begin{array}{l}\text { Developing } \\
\text { freshwater } \\
\text { giant prawn } \\
\text { culture }\end{array}$} \\
\hline $\begin{array}{l}\text { All male giant freshwater } \\
\text { prawn seed production }^{1}\end{array}$ & $\begin{array}{l}\text { Ben Gurion Univ. and Tiran } \\
\text { Co. }\end{array}$ & $\begin{array}{l}\text { Israeli } \\
\text { government }\end{array}$ & 2002 & \\
\hline $\begin{array}{l}\text { All male tilapia seed } \\
\text { production }^{2}\end{array}$ & $\begin{array}{l}\text { Asian Institute of } \\
\text { Technology (AIT) }\end{array}$ & SIDA & 1985 & \multirow{2}{*}{$\begin{array}{l}\text { Developing } \\
\text { tilapia industry }\end{array}$} \\
\hline $\begin{array}{l}\text { GIFT (Genetically } \\
\text { Improved Farmed Tilapia) } \\
\text { strain provision }^{3}\end{array}$ & WorldFish & UNDP & 1997 & \\
\hline $\begin{array}{l}\text { Seed production of } \\
\text { Pangasiid catfishes }{ }^{4}\end{array}$ & ORSTOM \& CIRAD & $\begin{array}{l}\text { Foreign } \\
\text { Ministry of } \\
\text { France }\end{array}$ & 1997 & $\begin{array}{l}\text { Developing } \\
\text { striped catfish } \\
\text { industry }\end{array}$ \\
\hline
\end{tabular}

Source: ${ }^{1}$ Research Institute for Aquaculture No. 2 (RIA2) (2021), ${ }^{2}$ Faculty of Fisheries - Nong Lam University HCMC (2021), ${ }^{3}$ Research Institute for Aquaculture No. 1 (RIA1) (2021), ${ }^{4}$ College of Aquaculture and Fisheries - Can Tho University (2021)

Moreover, the effectivity in technical training and transfer methods of provincial extension centers, particularly to small-scale households, have been improved by innovations brought into the country through international collaboration projects (Tuan, 2003). 


\section{Quick adaptation of technologies and innovations}

At the beginning of the development, aquaculture of Viet Nam, particular shrimp industry was behind its regional countries such as Thailand and the Philippines in terms of farming area and intensification (Hishamunda et al., 2009). Since the application of 'open door' policy of the country in mid-1980s, the sector had opportunities to access advanced techniques of the region and the world. After the success of domestic artificial seed production of BTS in 1985, the adaptation of aeration system with paddle wheels and imported pellet feeds from Thailand, the shrimp industry was quickly developed from extensive to semi- and intensive systems. Coping with problems of persistent white spot disease started in 1994, Thailand has gradually shifted from indigenous species (BTS) to imported one (WLS) since 2002. The recovery of Thailand's farming industry with high yield and disease resistance strains has encouraged the administrative agency to permit farming WLS at nation-wide level since 2008. Addition to the introduction of new species, the adaptation of technologies and innovations in hatcheries, feeds and feeding with automatic feeders, probiotic use combined with farming methods in biofloc and/or two-stage intensive systems, and biosecurity application has boosted the industry to a higher scale since mid-2010s (Hai et al., 2015).

\section{Cooperation among stakeholders}

Striped catfish farming requires high investment. Individual farmers cannot afford the cost of the operation. As a result, they have to link horizontally in the form of cooperatives and associations. In the production cost analysis, feed input occupies up to $86 \%$ of the total cost. Therefore, there is a vertical link between fish farmers and processing factories where the processing factories support the fish farmers by supplying feed and collect the harvested fish. Linked fish farmers usually have a contract to culture fish for processing factories (Loc et al., 2010).

Small-scale farmers are producers who operate low input farming systems such as extensive, integrated mangrove-shrimp and rotated rice-shrimp farming while large-scale farmers are those who run high input farming systems namely intensive farming. Different from the striped catfish industry which is dominated by large-scale farmers and companies, small-scale shrimp farmers also play important roles due to their contribution in terms of farming area and production. Intensive shrimp farming systems require high investment, but these ones are operated by individual farmers. Therefore, they link together to establish cooperatives and associations to have better sharing resources and supports from GOs and NGOs. However, there are almost no vertical links between frozen companies and farmers as compared to striped catfish industry (van Duijn et al., 2012). Since domestic market is an important one for shrimp products so intermediate traders such as wholesalers, middlemen and retailers contribute efficiently to shrimp distribution process.

\section{Support of NGOs}

At the first stage of the sector, aquaculture was promoted to develop aiming to alleviate the poverty, improve household income and achieve food security. Fisheries extension system was established from central to provincial levels. However, proper methodology of technique transfer, particularly for small-scale households was a big problem to the extension system. NGOs working for strengthening capacity of the poor have brought into Viet Nam new approaches such as fish Farmer Field Schools 
(FFS) assisting the small-scale households to obtain suitable know-hows and skills of fish culture more efficiently.

The NGOs have developed plans to create linkages among producers as well as between producers and other stakeholders throughout the value chain to improve profit and get a better support from different resources. Moreover, the NGOs have carried out programs to assist small farmers improving their production practice in compliant with criteria of international certification organizations. Many cooperatives of shrimp culture farmers operating low input systems in the MRD have obtained organic shrimp and ASC certificates. These certificates have improved production performance and profit of the cooperative members due to higher selling price and better environment protection (McEwin \& McNally, 2014).

\section{Challenges of Sustainable Development and Future Directions}

\section{Challenges of sustainable development}

Prolonged diseases of cultured animals are a big challenge of sustainable development (Thitamadee $e t$ al., 2016; Boerlage et al., 2017; Pongthanapanich et al., 2019; Ahmed et al., 2022). The prevalent diseases of striped catfish are enteric septicaemia (ES) and hemorrhagic disease (Pokhrel \& Oanh, 2021). Among diseases of shrimps, white spot (WSD), acute hepatopancreatic necrosis (AHPND) and slow growth (EHP) are the most serious (Duc et al., 2015). In the first semester of 2017, 18.9\% and $7.6 \%$ of cultured area was infected by hemorrhagic and enteric septicaemia diseases in the two largest producers of striped catfish in the MRD, namely An Giang and Dong Thap provinces. In nationwide, disease incidence of cultured marine shrimps occurred in 17-18 of 28 coastal provinces during the last three years (2018-2020).

Aquaculture production cost is continuously increased. This is contributed by increased cost of inputs included feed, medicines, chemicals and fuels, and low survival rate and high feed conversion ratio due to diseases, poor quality seed, inappropriateness of farming technique and management. In average, feed accounts for $75-85 \%$ of catfish production cost and $60-70 \%$ of shrimp production cost. Viet Nam feed industry relies heavily on imported ingredients such as fish meal. About 65-70 percent of feed ingredients are imported, including soybean meal, corn, distillers dried grains with solubles, feed wheat, and various kinds of meal and bran like copra, canola, rape seed meal, and wheat bran. Imported ingredients also include animal protein sources such as meat and bone meal, poultry byproduct meal and fish meal. This trend will continue as the feed industry continues to grow and local supply cannot keep pace with the increased demand from the feed industry. Aquafeed production has increased from 3.9 million MT in 2018 to 4.7 million MT in 2020 while home-made aquafeed was decreased from 2.5 million MT to 2.3 million MT in the same period (GAIN, 2019). Moreover, feed mills are dominated by FDI enterprises, and the government has not been able to manage the price of imported ingredients so far (StoxPlus Corporation, 2016).

Almost specific pathogen-free (SPF) and specific pathogen resistant (SPR) shrimp stocks are imported. Genetically improved brood-stock of striped catfish has been achieved in the country. However, access to high quality seed is difficult due to weak system for quality monitoring of traded seed and seed supply is under-required and untimely due to limited supply of selected brood-stock of 
striped catfish and shrimps. Genetically improved brood-stock supply is only fulfilling $60 \%$ of hatchery needs.

Although national export revenues have been increased yearly but export markets of seafood are unstable due to lack of market diversification. There is an increase of technical barrier and protectionism trend, particularly for striped catfish products, and competition among major producers, particularly among Asian countries, in global seafood markets.

Impacts of environmental degradation caused by poor production management, climate change and sea level rise which have not been fully evaluated have resulted in difficulties in the aquaculture sector such as increasing production cost, slow growth and low survival rates and high incidence of diseases (Thuoc, 1995; N. L. Anh, 2014; N. L. Anh et al., 2015; Cong, 2017; N. T. K. Anh et al., 2020). Although Viet Nam has launched many development plans of aquaculture in general, cultured species and regions, but there is inadequacy of issued ones due to lack of synchronism and interregionality. Investment for R\&D is low and lack of focus. Outdated and improper regulations and administrative formalities related to aquaculture production are slowly adjusted. Moreover, there is lack of support from administrative agencies and professional associations for certification and chain linkage building to local seafood producers (Hong et al., 2017).

\section{Future directions}

In 2018, Viet Nam was among top seven capture fisheries producers, accounted for $4 \%$ of the world capture fisheries production. Catch from inland fisheries of Viet Nam accounted for $1 \%$ of the world total. However, the contribution of the catch from inland fisheries has been declined. Aquaculture contributed 55.3\% of total fisheries production of the country. Viet Nam stands the fourth in terms of total aquaculture production, just behind China, India and Indonesia; in which inland aquaculture, marine and coastal aquaculture stand the fourth and the eighth, respectively. Viet Nam was also among major producers of crustaceans (the third) and mollusks (the fifth) (FAO, 2020).

To achieve development targets of the country, Viet Nam considers fisheries as one of major sectors of the economy. The country is implementing the Decision 339/QD-TTg dated March 11, 2021 by the Prime Minister on the "Viet Nam's fisheries development strategy for the period of 2021-2030, vision to 2045" (The Prime Minister of Viet Nam, 2021). The strategy set out several goals including developing the aquaculture industry in a more modern and competitive manner, enhancing mariculture in appropriate areas, enhancing the ability to deeply participate in global value chains, etc. At the same time mariculture development strategy for 2030 with a vision to 2045 is being developed and submitted by the MARD for government approval.

More potential water surfaces are exploited for developing aquaculture, particularly newly occurred saline-intruded areas due to climate change which cannot be continuously used for agricultural production purposes. Viet Nam has high potential for developing mariculture. However, the country is exposed to typhoons with increased incidence yearly. Therefore, inland and coastal aquaculture continue to account for the production of the sector.

There has been a better perception on balancing production for both local and global markets. Farming indigenous species have been developed in rural areas to actively supply food, create jobs, 
increase income for households, and contribute to poverty alleviation. Ready-to-cook products from striped catfish have been sold in many supermarkets around the country.

Global seafood market continues to increase with more concern on food safety, environmental protection and social equity (Subasinghe, 2003). Good aquaculture practice, production chain and traceability have also been accelerated to boost quality and exports (Quyen et al., 2020). Farming methods have been shifted to more intensification and less use of resources and improved to be more sustainable and suitable with natural conditions in different regions, particularly for shrimp production (N. T. T. Anh et al., 2019).

\section{Conclusion}

The sustainability of the aquaculture industry relies on many factors, such as good ecological conditions, natural resources, effective policies and regulations, infrastructure, and incorporation of new technologies on seed and farming production, as well as the support of the government and cooperation among stakeholders in the sector. Viet Nam has placed a high priority on aquaculture because of its perceived benefits in terms of food security, employment and foreign currency earning. It also encourages the private sector, welcoming investment from both domestic and foreign sources. Although the pace of the development has been slowdown but opportunities for further development of the industry are still exist. Much work remains to be done to guarantee the sustainability of the development included responsible farming practices and environmentally sound technologies. With the promotion of the government on developing synchronous infrastructure and technical facilities, and human resources; strengthening research, technology transfers and application of high technologies and digital transformation; reforming regulatory systems and improving state management and production re-organization capacity, it is firmly believed that Viet Nam aquaculture will be developed in a more sustainable manner in the future.

\section{Declaration of Interest Statement}

The authors declare no conflict of interest.

\section{References}

Ahmed, J., Khan, M. H., Unnikrishnan, S., \& Ramalingam, K. (2022). Acute hepatopancreases necrosis diseases (AHPND) as challenging threat in shrimp. Biointerface Research in Applied Chemistry, 12(1), 978 - 991. doi:10.33263/BRIAC121.978991

Anh, N. L. (2014). Climate proofing aquaculture: A case study on Pangasius farming in the Mekong Delta, Vietnam. (PhD thesis), Wageningen University, Wageningen, NL. Retrieved from https://edepot.wur.nl/325806

Anh, N. L., Minh, T. H., Verreth, J. A. J., Leemans, R., Bosma, R. H., \& De Silva, S. S. (2015). Exploring the climate change concerns of striped catfish producers in the Mekong Delta, Vietnam. SpringerPlus, 4(1), 46. doi:10.1186/s40064-015-0822-0

Anh, N. T. K., Anh, N. T. T., Jolly, C., \& Nguelifack, B. M. (2020). Economic efficiency of extensive and intensive shrimp production under conditions of disease and natural disaster risks in Khanh Hoa and Tra Vinh Provinces, Vietnam. Sustainability, 12(5), 2140.

Anh, N. T. K., Jolly, C. M., Chuong, B. N. P. T., \& Trang, L. T. H. (2016). Aquaculture and poverty alleviation in Ben Tre Province, Vietnam. Aquaculture Economics and Management, 20(1), 82-108. doi:10.1080/13657305.2016.1124938 
Anh, N. T. T., Anh, N. T. K., \& Jolly, C. (2019). Is super-intensification the solution to shrimp production and export sustainability? Sustainability, 11(19), 5277.

Boerlage, A. S., Dung, T. T., Hoa, T. T. T., Davidson, J., Stryhn, H., \& Hammell, K. L. (2017). Production of red tilapia (Oreochromis spp.) in floating cages in the Mekong Delta, Vietnam: mortality and health management. Diseases of Aquatic Organisms, 124(2), 131-144.

Cacot, P. (1998, May 11-15). Description of the sexual cycle related to the environment and set up of the artificial propagation in Pangasius bocourti (sauvage, 1880) and Pangasius hypophthalmus (Sauvage, 1878), reared in floating cages and in ponds in the Mekong Delta. Paper presented at the Mid-Term Workshop the Catfish Asia Project, Can Tho, Viet Nam.

College of Aquaculture and Fisheries - Can Tho University (2021). Research projects. Retrieved from https://caf.ctu.edu.vn/hop-tac-nckh/de-tai-cap-quoc-te.html

Cong, N. V. (2017). An overview of agricultural pollution in Vietnam: the aquaculture sector. (pp. 35). Prepared for the World Bank, Washington, DC: International Bank for Reconstruction and Development/The World Bank. Retrieved https://openknowledge.worldbank.org/bitstream/handle/10986/29243/122932-WP-P153343-PUBLICVietnam-aquaculture-ENG.pdf?sequence $=1$ \&isAllowed $=\mathrm{y}$

De Silva, S. S., \& Phuong, N. T. (2011). Striped catfish farming in the Mekong Delta, Vietnam: a tumultuous path to a global success. Reviews in Aquaculture, 3(2), 45-73. doi:https://doi.org/10.1111/j.1753-5131.2011.01046.x

Duc, P. M., Phuong, N. T., Hoa, T. T. T., Hien, H. V., Bosma, R. H., \& Tuan, T. N. (2015). Virus diseases risk factors associated with shrimp farming practices in rice-shrimp and intensive culture systems in Mekong Delta Viet Nam. International Journal of Scientific and Research Publications, 5(8), 1-6.

Edwards, P., Tuan, L. A., \& Allan, G. L. (2004). A survey of marine trash fish and fish meal as aquaculture feed ingredients in Vietnam. ACIAR Working Paper, No. 57, 56. doi:http://dx.doi.org/10.22004/ag.econ.118373

Faculty of Fisheries - Nong Lam University HCMC. (2021). Research projects. Retrieved from https://fof.hcmuaf.edu.vn/?lng=en\#

Food and Agriculture Organization of the United Nations (FAO). (2020). The state of world fisheries and aquaculture 2020: Sustainability in action. Rome, Italy. Retrieved from: http://www.fao.org/3/ca9229en/CA9229EN.pdf, pp. 206

Global Agricultural Information Network (GAIN). (2019). Vietnam - grain and feed annual (GAIN Report Number:VM9014). Retrieved from: https://apps.fas.usda.gov/newgainapi/api/report/downloadreportbyfilename?filename=Grain\%20and\% 20Feed\%20Annual_Hanoi_Vietnam_4-8-2019.pdf

General Statistics Office of Vietnam (GSO). (2019). Report on socio-economic status of the 4th quarter and whole year of 2019 (Report No. 209/BC-TCTK). Retrieved from: http://www.mpi.gov.vn/Pages/tinbai.aspx?idTin=44990\&idcm=293, pp. 38 (in Vietnamese).

General Statistics Office of Vietnam (GSO). (2021). Statistical data on fisheries. Retrieved from: https://www.gso.gov.vn/nong-lam-nghiep-va-thuy-san (in Vietnam).

Hai, T. N., Duc, P. M., Son, V. N., Minh, T. H., \& Phuong, N. T. (2015, March). Innovation in seed production and farming of marine shrimp in Vietnam. World Aquaculture, 46(1), 32-37.

Hishamunda, N., Bueno, P. B., Ridler, N., \& Yap, W. G. (2009). Analysis of aquaculture development in Southeast Asia: a policy perspective. Vol. No. 509. FAO Fisheries and Aquaculture Technical Paper (pp. 69). Rome, Italy: FAO. Retrieved from http://www.fao.org/docrep/012/i0950e/i0950e00.pdf

Hong, N. T. K., Hien, P. T. T., Thu, T. T. N., \& Lebailly, P. (2017). Vietnam's fisheries and aquaculture development's policy: are exports performance targets sustainable? Oceanography and Fisheries Open Access Journal, 5(4), 1-10. doi:10.19080/OFOAJ.2017.05.555667 
Japan International Cooperation Agency (JICA). (2013). Agricultural transformation and food security 2040 - Asean region with a focus on Vietnam, Indonesia, and Philippines - Vietnam country report. Retrieved from: https://openjicareport.jica.go.jp/pdf/12145546.pdf, pp. 156

Jonell, M., \& Henriksson, P. J. G. (2015). Mangrove-shrimp farms in Vietnam-Comparing organic and conventional systems using life cycle assessment. Aquaculture, 447, 66-75. doi:https://doi.org/10.1016/j.aquaculture.2014.11.001

Lam, P. T., Tam, B. M., Thuy, N. T. T., Gooley, G. J., Ingram, B. A., Hao, N. V., . . De Silva, S. S. (2009). Current status of farming practices of striped catfish, Pangasianodon hypophthalmus in the Mekong Delta, $\quad$ Vietnam. 227-236. doi:https://doi.org/10.1016/j.aquaculture.2009.08.017

Loc, V. T. T., Bush, S. R., Sinh, L. X., \& Khiem, N. T. (2010). High and low value fish chains in the Mekong Delta: challenges for livelihoods and governance. Environment, Development and Sustainability, 12(6), 889-908. doi:10.1007/s10668-010-9230-3

Ministry of Agriculture and Rural Development (MARD). (2015). Summarization report on Plan of Aquaculture development in the central coastline of Viet Nam to 2020 and orientation to 2030. Ha Noi, Viet Nam. Retrieved from: https://tongcucthuysan.gov.vn/Portals/0/bc-tong-hop-qh-ntts-mientrung-2020-2030.pdf, pp. 147 (in Vietnamese).

McEwin, A., \& McNally, R. (2014). Organic shrimp certification and carbon financing: an assessment for the mangroves and markets project in Ca Mau Province, Vietnam. (pp. 92). Retrieved from https://snv.org/assets/explore/download/140007_mangrove_shrimp_report_single-lr.pdf

Ministry of Fisheries (MoF), \& The World Bank (WB). (2005). Vietnam fisheries and aquaculture sector analysis - Final report. (pp. 49). Retrieved from https://documents1.worldbank.org/curated/en/955841468778172387/pdf/316950VN0white11 official0 use0only10.pdf

Nhut, N. (2016). Improving sustainability of striped catfish (Pangasianodon hypophthalmus) farming in the Mekong Delta, Vietnam, through recirculation technology. (PhD thesis), Wageningen University, Wageningen, NL. Retrieved from https://edepot.wur.nl/394644

Petteway, K. L. (2004). Free trade vs. protectionism: the case of catfish in context. North of Carolina Journal of International Law, 30(2), 474-514.

Pokhrel, S., \& Oanh, D. T. H. (2021). Investigation on common diseases of striped catfish (Pangasianodon hypophthalmus) farms in An Giang province and Can Tho City of the Mekong Delta, Vietnam. International Journal of Fisheries and Aquatic Studies, 9(3), 110-116.

Pongthanapanich, T., Nguyen, K. A. T., \& Jolly, C. M. (2019). Risk management practices of small intensive shrimp farmers in the Mekong Delta of Viet Nam. Vol. No. C1194. FAO Fisheries and Aquaculture Circular (pp. 30). Rome, Italy: Food and Agriculture Organization of the United Nations

Phuong, N. T., \& Minh, T. H. (2005). An overview of aquaculture sector in Vietnam. (pp. 1-14). NACA Publication. Retrieved from http://library.enaca.org/NACAPublications/NASO/Vietnam/NASO-Vietnam.pdf

Quyen, N. T. K., Hien, H. V., Khoi, L. N. D., Yagi, N., \& Karia Lerøy Riple, A. (2020). Quality management practices of intensive whiteleg shrimp (Litopenaeus vannamei) farming: a study of the Mekong Delta, Vietnam. Sustainability, 12(11), 4520.

Research Institute for Aquaculture No. 1 (RIA1). (2021). Research projects. Retrieved from http://ria1.org/ria1/Defaults.aspx?ctl=ListProject\&stID=64\&tab=64\&LangID=2

Research Institute for Aquaculture No. 2 (RIA2). (2021). Research projects. Retrieved from https://vienthuysan2.org.vn/index.php/vi/hoat-dong-nckh/De-tai-nghien-cuu-va-ket-qua/

Research Institute for Aquaculture No. 3 (RIA3). (2021). Research projects. Retrieved from https://www.ria3.vn/de-tai-du-an-11-0-acategory.html 
StoxPlus Corporation. (2016). Vietnam animal feed market review 2016. (pp. 21). Retrieved from https://pdf4pro.com/view/vietnam-animal-feed-market-review-2016-14e85.html

Subasinghe, R. P. (2003). An outlook for aquaculture development: major issues, opportunities and challenges. Vol. FAO Fisheries Circular. No. 886, Rev.2. FAO Inland Water Resources and Aquaculture Service: Review of the state of world aquaculture (pp. 31-36). Rome, Italy: FAO. Retrieved from http://www.fao.org/3/y4490E/y4490E02.pdf

Tam, B. M., Lam, P. T., Ingram, B. A., Thuy, N. T. T., Gooley, G. J., Hao, N. V., . . De Silva, S. S. (2010). Seed production practices of striped catfish, Pangasianodon hypophthalmus in the Mekong $\begin{array}{llll}\text { Delta } & \text { region, } & \text { Vietnam. } & \text { 9quaculture, }\end{array}$ doi:https://doi.org/10.1016/j.aquaculture.2010.06.016

Tu, N. V., Tu, N. P. C., \& Kha, N. H. N. (2019). Roles of research and education in freshwater aquaculture development: A case of striped catfish farming in Vietnam. In A. Figus \& T. Potempa (Eds.), Bologna Process and Fisheries Education for Sustainable Development (pp. 143-162): Eurolink University Press.

Tuan, L. A. (2003, January 1). Status of aquaculture and associated environmental management issues in Vietnam. from https://assets.publishing.service.gov.uk/media/57a08d01ed915d3cfd001764/RLAquaVietnamaquacult ureR8094.pdf

The Prime Minister of Viet Nam. (2021). Decision 339/QD-TTg dated March 11, 2021 on approving the strategy of developing Vietnam's fisheries to 2030, with a vision to 2045.

Thitamadee, S., Prachumwat, A., Srisala, J., Jaroenlak, P., Salachan, P. V., Sritunyalucksana, K., . . . Itsathitphaisarn, O. (2016). Review of current disease threats for cultivated penaeid shrimp in Asia. Aquaculture, 452, 69-87. doi:https://doi.org/10.1016/j.aquaculture.2015.10.028

Thuoc, P. (1995). Annex II-17: Country reports - Vietnam. Regional Study and Workshop on the Environmental Assessment and Management of Aquaculture Development (TCP/RAS/2253). NACA Environment and Aquaculture Development Series No. 1. Network of Aquaculture Centres in AsiaPacific, Bangkok, Thailand. Retrieved from http://www.fao.org/3/ac279e/AC279E20.htm\#annII17

van Duijn, A. P., Beukers, R., \& van der Pijl, W. (2012). The Vietnamese seafood sector: A value chain analysis. (pp. 89). LEI - Wageningen UR: Centre for the Promotion of Imports from Developing Countries (CBI). Retrieved from https://edepot.wur.nl/237935

Vietnam Association of Seafood Exporters and Producers VASEP. (2021). Overview of fisheries sector of Viet Nam. Retrieved from http://vasep.com.vn/gioi-thieu/tong-quan-nganh

Viet, T. V. (2013). Roles of fisheries in social economic developments in the Mekong delta, Vietnam. Scientific Journal of Can Tho University, Part B: Agriculture, Fisheries and Biotechnology, 27, 136144.

Vinh, D. T. T. (2006). Aquaculture in Vietnam: development perspectives. Development in Practice, 16(5), 498-503. doi:10.1080/09614520600792549 